\title{
Can Tall Guinea-Race Sorghum Hybrids Deliver Yield Advantage to Smallholder Farmers in West and Central Africa?
}

\author{
Moctar Kante, Henry Frederick W. Rattunde,` Willmar L. Leiser, Baloua Nebié, Bocar Diallo, Abdoulaye \\ Diallo, Abocar Oumar Touré, Eva Weltzien, and Bettina I.G. Haussmann
}

\begin{abstract}
Many farmers in West and Central Africa (WCA) prefer tall (>3 $\mathrm{m})$ grain sorghum [Sorghum bicolor (L.) Moench] for various reasons. This study seeks to determine (i) what yield superiority newly bred, tall, photoperiod-sensitive guinearace sorghum hybrids can provide relative to an adapted landrace variety across a wide range of productivity conditions, and (ii) the risk of these hybrids failing to provide yield superiority for individual farmers. Seven hybrids, one local check, and eight pure-line progenies were evaluated in 37 farmer-managed, on-farm yield trials across three Malian zones and 3 yr. Environments were classified into four productivity groups (low $[0.78-1.10 \mathrm{Mg}$ ha $^{-1}$, mid-low [1.10-1.50 $\left.\mathrm{Mg} \mathrm{ha}^{-1}\right]$, mid-high [1.50-2.00 $\left.\mathrm{Mg} \mathrm{ha}^{-1}\right]$ and high [2.00-2.65 $\left.\mathrm{Mg} \mathrm{ha}^{-1}\right]$ ) based on their trial mean grain yield. Mean yields of the seven tall hybrids were 3 to $17 \%$ (ranging from 0.06 to $0.28 \mathrm{Mg} \mathrm{ha}^{-1}$ ) higher than that of the local check across all environments and were highest (14-47\%) averaged across the seven trials with the lowest mean yields. The individual overall highest-yielding hybrid showed superiorities over the local check in the low, mid-low, mid-high, and high productivity levels of $0.43(47 \%), 0.14(10 \%), 0.47(27 \%)$, and 0.34 (14\%) $\mathrm{Mg} \mathrm{ha}^{-1}$, respectively. The tall hybrids rarely had yields significantly inferior to the local check. Farmers' preference for, and the possible benefits of, taller plant types may lead farmers to grow tall hybrids, particularly under the typical low-productivity production conditions of WCA.
\end{abstract}

M. Kante and B.I.G. Haussmann, Institute of Plant Breeding, Seed Science and Population Genetics, Univ. of Hohenheim, 70599 Stuttgart, Germany; H.F.W. Rattunde and E. Weltzien, Univ. of Wisconsin-Madison, Madison, WI; W.L. Leiser, State Plant Breeding Institute, Univ. of Hohenheim, 70599 Stuttgart, Germany; B. Nebié, International Crops Research Institute for the Semi-Arid Tropics, BP 320, Bamako, Mali; B. Diallo, A. Diallo, and A.O. Touré, Institut d'Economie Rurale, BP 262, Bamako, Mali. Received 14 Sept. 2016. Accepted 14 Dec. 2016. ^Corresponding author (f.rattunde@gmail. com). Assigned to Associate Editor Majit S. Kang.

Abbreviations: AMMI, additive main effect and multiplicative interaction; EM, expectation maximization; GEI, genotype-byenvironment interaction; ICRISAT, International Crops Research Institute for the Semi-Arid Tropics; IER, Institut d'Economie Rurale; IPC, interaction principal component; Kp, photoperiod sensitivity index; PLEC, pure-line experimental cultivars; WCA, West and Central Africa.

Corghum BICOLOR (L.) Moench is a major staple cereal crop in $\checkmark$ the savannah zone of West and Central Africa (WCA) that is typically grown under low-input conditions. Soil fertility levels are generally low in these cropping systems (Jones and Wild, 1975; Bationo et al., 2007). With population growth contributing to rising demand, the area of sorghum production is steadily increasing (FAOSTAT, 2015), yet sorghum productivity has not increased substantially during the past $50 \mathrm{yr}$; the long-term sorghum grain yield in WCA averages approximately $1 \mathrm{Mg} \mathrm{ha}^{-1}$ (Chantereau et al., 2013; FAOSTAT, 2015).

The guinea race, one of the five major sorghum races (Harlan and de Wet, 1972), being vital for food security in the Sudanian and Northern Guinea zones of Senegal, Mali, and Burkina Faso, is extensively cultivated in WCA (de Wet and Huckabay, 1967). The guinea race has the broadest geographical distribution

Published in Crop Sci. 57:1-10 (2017).

doi: $10.2135 /$ cropsci2016.09.0765

(C) Crop Science Society of America | 5585 Guilford Rd., Madison, WI 53711 USA This is an open access article distributed under the CC BY-NC-ND license (http://creativecommons.org/licenses/by-nc-nd/4.0/). 
(de Wet et al., 1972; Harlan and de Wet, 1972) and greatest genetic diversity of the major sorghum races (Folkertsma et al., 2005; Billot et al., 2013). This race, domesticated in WCA (Dahlberg, 2000), has hard grains of symmetrical form that twist relative to widely opening glumes at maturity in lax panicles.

Despite the creation of new shorter-statured varieties, many farmers still grow landrace varieties that are tall (>3 m) and photoperiod sensitive (Kimber et al., 2013). The photoperiod sensitivity and taller plant height reduce grain-mold damage and bird predation by enabling optimal timing of grain filling near the end of the rainy season, better shedding of rain water, and hindering birds from roosting on the swaying, drooping, lax panicles born on long peduncles. Further, the taller height can aid in competition with weeds and reduce risks of panicle loss by grazing transhumant cattle.

Sorghum hybrid breeding began in 1927 (Conner, 1927), but commercial hybrids were feasible only after the identification of a heritable and stable cytoplasmic male sterility (CMS) mechanism (Stephens and Holland, 1954). Sorghum hybrids have shown potential to outyield their parents and local varieties under drought conditions in Eastern Africa (Blum et al., 1992; Haussmann et al., 1997, 1998, 1999, 2000). Hybrid crosses of Malian landraces with introduced caudatum-race seed parents showed good heterosis for grain yield, but they lacked the grain quality required for production in the guinea-race zone of WCA (Touré and Scheuring, 1982). These results, and farmers' demand for higher-yielding varieties, motivated the Institut d'Economie Rurale (IER) and the International Crops Research Institute for the Semi-Arid Tropics (ICRISAT) in Mali to test the feasibility of breeding hybrids based on photoperiod-sensitive, guinea-race germplasm (Smale et al., 2014; Weltzien, 2014). The shorter ( $<3 \mathrm{~m})$ hybrids from the first series of guinea-race hybrids combined good grain quality with grain yield superiorities of up to $37 \%$ over the highly appreciated guinea landrace variety 'Tieble' under farmers' field conditions (Rattunde et al., 2013).

Therefore, the objectives of this study were (i) to determine the yield performance of tall photoperiodsensitive sorghum hybrids relative to farmers' adapted landrace varieties under a range of Malian farmers' production conditions and (ii) to understand what, if any, risk these new tall hybrids may pose for not recovering the farmer's investment in purchased hybrid seed through sufficient yield superiorities.

\section{MATERIALS AND METHODS Genotypes}

Based on grain yield and plant height data from trials at the IER and ICRISAT research stations near Bamako, Mali, in 2007 and 2008 , seven tall sorghum hybrids $(>3 \mathrm{~m})$ were identified for farmer-participatory testing out of a set of 55 hybrids. The seven hybrids in this study were produced using two A1 cytoplasmic male-sterile seed parents, either the tall FambeA or the shorter (intermediate stem internode length) GP271A (Supplemental Table S1). The maintainer line for FambeA was derived from a mutagenized Malian guinea landrace variety, and that for GP271A was derived from an ICRISAT-IER random-mating population based on guinea landrace germplasm (Rattunde et al., 1997). The male parents consisted of four restorer lines derived from tall guinea landrace varieties (IS2731 from Burkina Faso, CSM388 and CSM63E from Mali, and Zabuwa from Nigeria) and two breeding lines with intermediate stem internode lengths (Lata, derived from a random-mating guinea-race population, and CGM 19/9-1-1 from a biparental guinea-race cross).

The eight pure-line experimental cultivars (PLEC) included in the farmer participatory yield trials were derived by IER in the $F_{5}$ generation from interracial guinea-caudatum material. They were identified on the basis of high yields in initial yield trials conducted at IER research stations (Cinzana, Bema, Sotuba, and Kolombada).

The tall landrace cultivar Tieble (CSM335 from the Malian Collection), highly appreciated by farmers for its yield stability and good grain quality, was included in the trial as a local check variety. One hybrid (Wagui) was dropped after the first-year (2009) trials because it was clearly rejected by farmers on account of its late maturity. This hybrid was replaced by a second, slightly late-maturing Malian landrace, Doua-G, for the second- (2010) and third-year (2011) trials.

\section{Participatory On-Farm Yield Trials}

Thirty-seven on-farm yield trials were conducted in three of the major sorghum production zones of Mali: the Dioila and Koutiala zones with more intensified agriculture and strong history of cotton (Gossypium hirsutum L.) production, and the Mande zone with less intensified agriculture. The on-farm yield trials were conducted in three villages per zone (four villages in Dioila 2009), with two farmers chosen per village across two consecutive years (2009-2010 for Dioila and Mande, and 2010-2011 for Koutiala) (Table 1), involving a total of 26 participating farmers as part of an ongoing participatory sorghum cultivar-testing program (Weltzien et al., 2008).

An $\alpha$-lattice design, with two replications and four blocks of four plots per replication, was used for all on-farm trials. Plots consisted of six rows of $5-\mathrm{m}$ length, with approximately $75 \mathrm{~cm}$ between rows and $40 \mathrm{~cm}$ between hills. Plots were sown with six seeds per hill, and hills were finally thinned to two plants around 4 wk after sowing. Sowing, weeding, thinning, and fertilization were conducted by the farmers. Sufficient fertilizer and calibrated measuring cups were provided to the farmers for manual application of $100 \mathrm{~kg} \mathrm{ha}^{-1}$ of diammonium phosphate and $50 \mathrm{~kg} \mathrm{ha}^{-1}$ of urea, which were generally applied after the first and second weedings, respectively.

Additional field trials were sown at the ICRISATMali research station in the same field on 15 July 2009 and 26 June 2010 using an $\alpha$-lattice design with four replicates. Plant heights and dates of 50\% anthesis were recorded, and a photoperiod-sensitivity index $(\mathrm{Kp})$ was computed using the following equation:

$$
\mathrm{Kp}=(\text { DurF1 }- \text { DurF2) } /(\text { DS2 }- \text { DS1 })
$$


Table 1. Number of on-farm trials ( $\mathrm{N}$ trials), sowing date ranges, precipitation (PPT), and mean grain yield by zone and by year

\begin{tabular}{lcccccc}
\hline Zones & \multicolumn{3}{c}{ Mande } & \multicolumn{3}{c}{ Dioila } \\
\hline Year & 2009 & 2010 & 2009 & 2010 & 2010 \\
N trials & 6 & 6 & 8 & 6 & 6 & 2011 \\
Sowing dates & $8-27$ July & 28 June-14 July & $9-19$ July & $15-30$ June & $14-28$ June & 23 June-15 July \\
Total PPT (mm) & 821 & 932 & 742 & 1088 & 1279 \\
August PPT (mm) & 223 & 214 & 1.43 & 350 & 326 \\
Yield (Mg ha $\left.{ }^{-1}\right)$ & 1.43 & 1.43 & 1.46 & 175 \\
\hline
\end{tabular}

where DurF1 and DurF2 are the duration in days from sowing to $50 \%$ anthesis in the 26 June and 15 July sowings, respectively, and DS1 and DS2 are the first and second sowing dates in Julian days (Clerget and Rattunde, 2007). The value of $\mathrm{Kp}$ is expected to vary from zero, for photoperiod-insensitive cultivars that do not change the duration of their vegetative phase, to one, for the most strongly photoperiod-sensitive cultivars that reduce their vegetative phase to the same extent as the delay in sowing (19 d, in this case).

\section{Statistical Analysis}

Each farmer's trial in a given year was considered a separate environment. A mixed-model analysis using restricted maximum likelihood (REML) was conducted with the software GenStat, 17th edition (VSN International, 2014) to analyze the phenotypic data from the 37 on-farm environments across $3 \mathrm{yr}$. Single-environment data were first analyzed separately, treating replications as fixed and blocks nested within replications and genotypes as random. Repeatability (broad-sense heritability of single trials) estimates for each trial were based on an ad hoc approach for unbalanced datasets using formula 19 in Piepho and Möhring (2007). The average variance of differences among genotypes and the best linear unbiased estimates (BLUEs) of each genotype in each environment were obtained from a second model where genotypes were considered a fixed factor. Least significant differences (LSD, $\alpha=5 \%$ ) per environment were computed to compare genotypic means.

Environments were classified into four groups (low [0.78$1.10 \mathrm{Mg} \mathrm{ha}^{-1}$ ], mid-low [1.10-1.50 $\mathrm{Mg} \mathrm{ha}^{-1}$ ], mid-high [1.50-2.00 $\left.\mathrm{Mg} \mathrm{ha}^{-1}\right]$, and high [2.00-2.65 $\left.\mathrm{Mg} \mathrm{ha}^{-1}\right]$ ) based on their trial mean grain yield. A combined analysis of grain yield across all on-farm trials was done using a hierarchical model, treating all factors as random. Two separate multi-environment combined analyses were conducted, modeling a heterogeneous error term to account for the variable yield and error levels among environments. In the first analysis, we used a hierarchical model (Eq. [2]) with replications nested within environments and incomplete blocks nested within replications. From this model, we obtained the reference variance components, particularly for the genotype-by-environment interaction (GEI), the best linear unbiased predictors (BLUPs) for the genotypes, and an estimate of broadsense heritability across all environments using formula 20 of Piepho and Möhring (2007). In the second analysis (Eq. [3]), we added environmental variables, one at a time, to examine the contributions of agroecological zone (Mande, Dioila, and Koutiala), yield level (four levels) ,or year to GEI (Leiser et al., 2012).

$$
\begin{aligned}
Y_{i j k l} & =\mu+G_{i}+E_{j}+G_{i j} \\
& +E(R)_{j k}+E[R(B)]_{j k l}+\varepsilon_{i j k l}
\end{aligned}
$$

$$
\begin{aligned}
Y_{i j m k l}= & \mu+G_{i}+E_{j}+\mathrm{GE}_{i j}+\mathrm{GF}_{i m} \\
& +E(R)_{j k}+E[R(B)]_{j k l}+\varepsilon_{i j m k l}
\end{aligned}
$$

where $Y_{i j k l}$ is the observed yield value with the $i$ th genotype in the lth incomplete block within the $k$ th replication of the $j$ th environment, $G_{i}$ is the effect of the $i$ th genotype, $E_{j}$ the effect of the $j$ th environment, $R_{k}$ is the effect of the $k$ th replication and $B_{l}$ the effect of the 1 th block within the $k$ th replication in the $j$ th environment. $Y_{i j m k l}$ is the observed yield value of the $i$ th genotype in the $l$ th incomplete block within the $k$ th replication of the $j$ th environment and the $m$ th environmental factor level. GF $_{i m}$ denotes the interaction effect of the $i$ th genotype with the $m$ th environmental factor (e.g., zone, year, and yield level). $\mathrm{GE}_{i j}$ denotes the interaction effect of the $i$ th genotype with the jth environment. $\varepsilon_{i j k l}$ and $\varepsilon_{i j m k l}$ are the residual terms of the respective model.

The additive main effect and multiplicative interaction (AMMI) analysis and biplot (Gauch and Zobel, 1988; Gauch, 2013) were computed with the agricolae package (de Mendiburu, 2009) under the $\mathrm{R}$ software ( $\mathrm{R}$ Development Core Team, 2011). Prior to the AMMI analysis, missing data were imputed, applying the expectation maximization (EM) algorithm (Gauch and Zobel, 1990) with the EM.AMMI function (Paderewski, 2013) in R. The genotypes Wagui (hybrid) and DouaG (local variety) were removed from the analysis because they were not present across all years and therefore would have a strong dependency on the imputation algorithm.

Yield stability of hybrids and Tieble across all environments was assessed by regressing the single-environment yields of each genotype against the respective environmental mean yields (Finlay and Wilkinson, 1963; Lin et al., 1986; Becker and Leon, 1988). The analysis was done using the Finlay and Wilkinson analysis tool implemented under Genstat 18th edition (VSN International, 2015).

\section{RESULTS}

\section{Individual On-Farm Trials and Repeatabilities}

Mean grain yields of the 37 on-farm trials varied from 0.78 to $2.60 \mathrm{Mg} \mathrm{ha}^{-1}$ and genotypic mean yields within environments ranged from 0.37 to $3.74 \mathrm{Mg} \mathrm{ha}^{-1}$. Although the trials were sown across a 6 -wk period, between 14 June and $27 \mathrm{July}$, no relationship was observed between sowing date and trial mean grain yield $(r=0.11, p=0.53, n=37)$. Repeatability estimates for grain yield varied between 0.13 and 0.90 (median $=0.78$ ) for individual trials, with only one having a repeatability below 0.57 (Supplemental Fig. S1, Supplemental Table S2), and had no significant relationship with mean grain yield $(r=0.23, p=0.18, n=36)$. 


\section{Genetic Differences and Genotype-by- Environment Interaction}

Although the GEI was significant, the significant genotypic variance component was more than double the GEI variance component (Table 2). Inclusion of specific environmental factors to account for geographic zones, years, or productivity levels in the combined analysis reduced the GEI variance by only $11.7,7.4$, and $8.7 \%$, respectively, relative to the original GEI variance; hence, these factors did not substantially explain the GEI variance. The broadsense heritability estimate was 0.91 , and combined analysis within each zone revealed significant GEI interaction only within the Dioila zone (Supplemental Table S3).

The AMMI analysis explained 28.6 and $19.4 \%$ of GEI with the first and second interaction principal components (IPC1 and IPC2), respectively, with no detection of clearly distinct mega-environments (Fig. 1). The hybrids (entries 9-14) exhibited greater GEI than PLECs, with the GEI of hybrids over the higher productivity environments being markedly greater than over the lower-yielding environments (Fig. 1, further hierarchical combined analysis [data not shown]). The PLECs (entries 1-8) and the local check Tieble (entry 16) had little to no interactive behavior, as indicated by their small to near-zero IPC1 and IPC2 scores. The two highest-yielding hybrids, Pablo (entry 9) and Caufa (entry 13), had the highest interactive behavior, displaying the largest yield ranges across environments, with minimums of 0.95 and 0.72 and maximums of 3.47 and $3.69 \mathrm{Mg} \mathrm{ha}^{-1}$, respectively, across single environments.

\section{Hybrid Performance Relative to the Local Check}

The mean grain yields of the experimental hybrids ranged from 1.70 to $1.92 \mathrm{Mg} \mathrm{ha}^{-1}$, which represented yields of 0.06 to $0.28 \mathrm{Mg} \mathrm{ha}^{-1}$ (3-17\%) higher than that of the local check Tieble, averaged across all 37 yield trials (Table 3 ). The hybrids, as a group, exhibited grain yields that were numerically higher than that of Tieble in the lower- and higher-yielding conditions (Table 4). However, only in the lowest productivity level was the hybrid mean significantly superior to Tieble's mean yield, with both the absolute and percentage mean yield advantage of hybrids being greater than in the higher-productivity levels (Table 4). The hybrid with the overall highest yield, Pablo, had a $0.43-\mathrm{Mg} \mathrm{ha}^{-1}$ average yield superiority (47\%) over Tieble in the lowest productivity trials and only a $0.34-\mathrm{Mg} \mathrm{ha}^{-1}$ superiority (14\%) in the highest productivity trials (Table 4).

Although there were cases of hybrids yielding less than Tieble in individual trials (Fig. 2), the frequency of significantly inferior yield was below $5 \%$ in all productivity levels, except mid-high, where it was 7\% (Table 4). Out of 230 pairwise yield comparisons between Tieble and individual hybrids across all trials, in only nine comparisons did Tieble significantly (LSD, $\alpha=5 \%$ ) outperform a hybrid.
Table 2. Estimates of variance components ( \pm SE) for genotypic $\left(\sigma_{\mathrm{g}}^{2}\right)$, environmental $\left(\sigma^{2}\right)$, and genotype-byenvironment interaction $\left(\sigma^{2}{ }_{g e}\right)$ sources of variance for sorghum grain yield over 37 on-farm trials and for the residual genotype-by-environment interaction (GEI) variance components after accounting for zone, year, and yield group.

\begin{tabular}{|c|c|}
\hline Term & Variance component $( \pm \mathrm{SE}) \dagger$ \\
\hline$\sigma_{g}^{2}$ & $4.72^{\star \star}( \pm 1.75)$ \\
\hline$\sigma_{e}^{2}$ & $20.46^{\star \star \star}( \pm 5.17)$ \\
\hline$\sigma_{g e}^{2}$ & $2.21^{\star \star \star}( \pm 0.46)$ \\
\hline \multicolumn{2}{|c|}{ Residual GEl variance $( \pm$ SE) after accounting for: } \\
\hline Zone & $1.95^{\star \star \star}( \pm 0.44)$ \\
\hline Year & $2.05^{\star \star \star}( \pm 0.46)$ \\
\hline Yield group & $2.02^{* \star *}( \pm 0.45)$ \\
\hline
\end{tabular}

** Significant at the 0.01 probability level.

${ }^{\star \star \star}$ Significant at the 0.001 probability level.

† Variance components were multiplied by 100 for better readability.

Individual hybrids had significantly higher yield than Tieble in 42 cases, with Pablo (11) and Caufa (9) accounting for half of these cases. Whereas the hybrids exhibited significant superiority to Tieble in $31 \%$ of the comparisons among the seven lowest-yielding trials, among the eight highest-yielding trials, they did so in only $17 \%$ of the pairwise comparisons. The hybrids Pablo and Wagui were among the top four hybrids that outperformed Tieble across all four yield groups (Supplemental Table S4).

Based on the linear regression analysis (Supplemental Fig. S2), Pablo (slope $b=1.21)$ and Tieble $(b=1.12)$ had

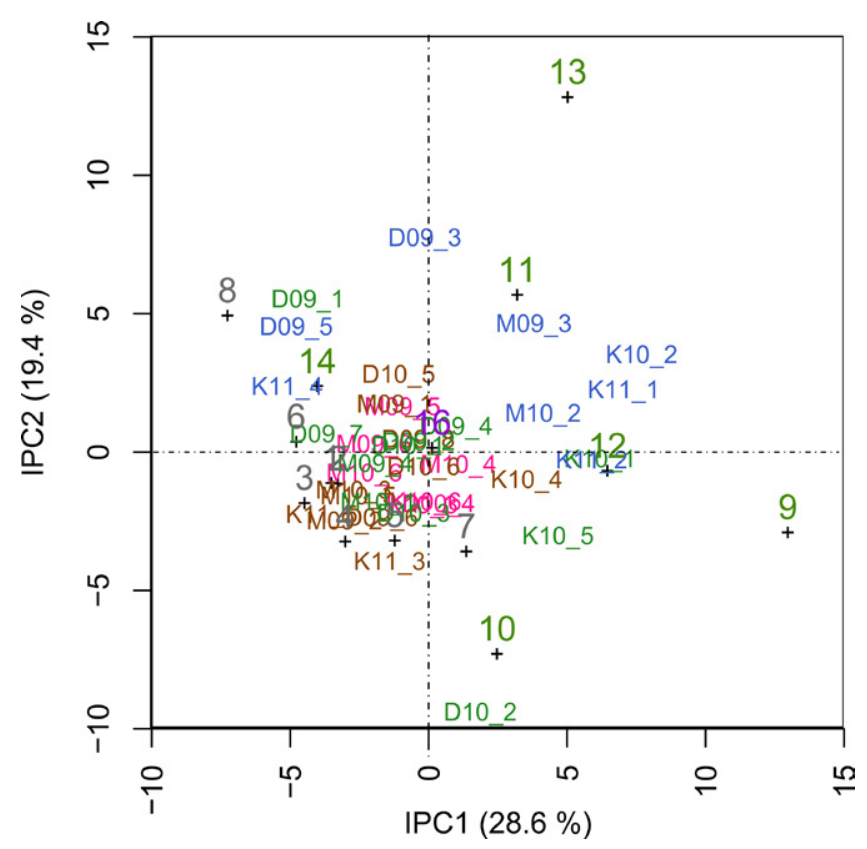

Fig. 1. Additive main effect and multiplicative interaction (AMMI) 2 biplot of 15 Guinea sorghum cultivars (hybrids in green, local check in violet, and pure-line experimental cultivars [PLECs] in grey) tested in 37 on-farm trials in Mali between 2009 and 2011. The environments in low-, mid-low-, mid-high-, and high-yielding environments are respectively in pink, brown, green, and blue. Entry numbers and codes for environments are described in Table 3 and in Supplemental Table S2, respectively. 
Table 3. Grain yields ( $\mathrm{Mg} \mathrm{ha}^{-1}$ ) and plant height $(\mathrm{cm})$ best linear unbiased predictors (BLUPs) of 17 sorghum cultivars over 37 on-farm trials and the absolute value and difference of each cultivar's grain yield relative to 'Tieble', as well as their dates of $50 \%$ heading and photoperiod sensitivity indices $(\mathrm{Kp})$ from ICRISAT Bamako research station trials.

\begin{tabular}{|c|c|c|c|c|c|c|c|c|}
\hline Entry number & Name & Type† & Grain yield & $\begin{array}{l}\text { Difference } \\
\text { over Tieble }\end{array}$ & Superiority & $\begin{array}{l}\text { Mean plant } \\
\text { height }\end{array}$ & $\begin{array}{c}50 \% \\
\text { heading } \ddagger\end{array}$ & Kp§ \\
\hline & & & \multicolumn{2}{|c|}{$-\mathrm{Mg} \mathrm{ha}^{-1}-$} & $\%$ & $\mathrm{~cm}$ & Julian d & \\
\hline 9 & Pablo & Hyb & 1.92 & 0.28 & 17 & 317 & 265 & 0.91 \\
\hline 13 & Caufa & Hyb & 1.86 & 0.21 & 13 & 323 & 266 & 0.92 \\
\hline 11 & Omba & Hyb & 1.85 & 0.20 & 12 & 343 & 268 & 0.88 \\
\hline $15 \mathrm{a}$ & Waguiף & Hyb & 1.78 & 0.14 & 8 & 345 & & - \\
\hline 12 & Niakafa & Hyb & 175 & 0.10 & 6 & 343 & 264 & 0.81 \\
\hline 14 & Teli & Hyb & 1.75 & 0.10 & 6 & 310 & 263 & 0.81 \\
\hline 10 & Yamasa & Hyb & 1.70 & 0.06 & 3 & 342 & 268 & 0.75 \\
\hline 8 & Jamajigi & PLEC & 1.63 & -0.02 & -1 & 193 & 271 & 0.75 \\
\hline 7 & Fatoma & PLEC & 1.48 & -0.17 & -10 & 329 & 255 & 0.30 \\
\hline 5 & Kemessou & PLEC & 1.46 & -0.18 & -11 & 284 & 258 & 0.58 \\
\hline 2 & Sotigui & PLEC & 1.45 & -0.20 & -12 & 324 & 257 & 0.33 \\
\hline 1 & Babalissa & PLEC & 1.34 & -0.30 & -18 & 269 & 249 & -0.03 \\
\hline 6 & Keneya & PLEC & 1.33 & -0.32 & -19 & 311 & 256 & 0.54 \\
\hline 3 & Kolo & PLEC & 1.31 & -0.33 & -20 & 310 & 257 & 0.21 \\
\hline 4 & Kamaleni & PLEC & 1.22 & -0.42 & -26 & 324 & 258 & 0.28 \\
\hline $15 b$ & DouaGף & LVC & 1.58 & -0.07 & -4 & - & 272 & 0.91 \\
\hline 16 & Tieble & LVC & 1.65 & & & 332 & 269 & 0.80 \\
\hline LSD (5\%) & & & & 0.11 & 7 & 14 & & \\
\hline
\end{tabular}

† Hyb, hybrid experimental cultivar; PLEC, pure-line experimental cultivar; LVC, landrace-cultivar check.

‡ Based on data from 2010 trial sown on 26 June (177 Julian d).

§ Calculated using Eq. [1] and heading dates from 2009 (196 Julian d sowing) and 2010 (177 Julian d sowing).

If Wagui was tested only in 2009 and replaced in 2010 and 2011 by DouaG.

Table 4. Genetic $\left(\sigma_{g}^{2}\right)$ and genotype-environment interaction $\left(\sigma_{\mathrm{ge}}^{2}\right)$ variance components and grain yields, hybrid to local check 'Tieble' yield comparisons, and plant heights within sets of on-farm trials grouped by trial mean productivity level.

\begin{tabular}{|c|c|c|c|c|}
\hline & \multicolumn{4}{|c|}{ Trial yield level† } \\
\hline & Low & Mid-low & Mid-high & High \\
\hline Number of trials & 7 & 11 & 11 & 8 \\
\hline$\sigma^{2} / \sigma^{2}$ for grain yield $\neq$ & $3.97^{\star} / 1.16^{\mathrm{NS}}$ & $3.30 * / 2.31^{* *}$ & $5.56^{\star} / 2.31^{\mathrm{NS}}$ & $16.40^{\star} / 9.48^{\star}$ \\
\hline Mean yield of individual trials (range $\mathrm{Mg} \mathrm{ha}^{-1}$ ) & $0.78-1.10$ & $1.14-1.50$ & $1.54-1.99$ & $2.07-2.60$ \\
\hline Mean yield over all trials $\left(\mathrm{Mg} \mathrm{ha}^{-1}\right)$ & 1.00 & 1.33 & 1.73 & 2.31 \\
\hline Mean yield of Tieble $\left(\mathrm{Mg} \mathrm{ha}^{-1}\right)$ & $0.92^{\mathrm{SH}}$ & $1.47^{\mathrm{NSH}}$ & $1.73^{\mathrm{NSH}}$ & $2.51^{\mathrm{NSH}}$ \\
\hline Mean yield of all hybrids $\left(\mathrm{Mg} \mathrm{ha}^{-1}\right)$ & 1.23 & 1.51 & 1.97 & 2.73 \\
\hline Mean yield of best hybrid $\left(\mathrm{Mg} \mathrm{ha}^{-1}\right)$ & $1.41^{\mathrm{a}}$ & $1.63^{b}$ & $2.20^{\circ}$ & $3.23^{a}$ \\
\hline Mean yield of hybrid Pablo§ $\left(\mathrm{Mg} \mathrm{ha}^{-1}\right)$ & 1.35 & 1.61 & 2.20 & 2.85 \\
\hline Mean yield of individual trials (range $\mathrm{g} \mathrm{m}^{-2}$ ) & $78-110$ & $114-150$ & $154-199$ & $207-260$ \\
\hline Mean yield over all trials $\left(\mathrm{g} \mathrm{m}^{-2}\right)$ & 100 & 133 & 173 & 231 \\
\hline Mean yield of Tieble $\left(\mathrm{g} \mathrm{m}^{-2}\right)$ & $92^{\mathrm{SH}}$ & $147^{\mathrm{NSH}}$ & $173^{\mathrm{NSH}}$ & $251^{\mathrm{NSH}}$ \\
\hline Mean yield of all hybrids $\left(\mathrm{g} \mathrm{m}^{-2}\right)$ & 123 & 151 & 197 & 273 \\
\hline Mean yield of best hybrid $\left(\mathrm{g} \mathrm{m}^{-2}\right)$ & $141^{\mathrm{a}}$ & $163^{b}$ & $220^{c}$ & $323^{a}$ \\
\hline Mean yield of hybrid Pablo§ $\left(\mathrm{g} \mathrm{m}^{-2}\right)$ & 135 & 161 & 220 & 285 \\
\hline Yield superiority of all hybrids over Tieble (\%) & 33.7 & 2.7 & 13.9 & 8.8 \\
\hline Yield superiority of hybrid Pablo§ over Tieble (\%) & $46.7^{\star \star}$ & $9.5^{\mathrm{NS}}$ & $27.2^{\star \star \star}$ & $13.6^{\star \star}$ \\
\hline Pairwise comparisons of hybrid vs. Tieble (total count) & 44 & 70 & 71 & 45 \\
\hline Pairwise comparisons with significant $(P<0.05)$ hybrid yield inferiority relative to Tieble (\%) & 2.3 & 4.3 & 7.0 & 0.0 \\
\hline Pairwise comparisons with significant $(P<0.05)$ hybrid yield superiority relative to Tieble $(\%)$ & 31.8 & 18.6 & 28.2 & 17.8 \\
\hline Mean plant height $\emptyset$ Tieble (cm) & 292 & 299 & 368 & 406 \\
\hline Mean plant height $\uparrow$ all hybrids (cm) & 285 & 306 & 346 & 401 \\
\hline Mean plant height $\uparrow$ of within group highest yielding hybrid $(\mathrm{cm})$ & $293^{a}$ & $315^{\mathrm{b}}$ & $345^{c}$ & $393^{a}$ \\
\hline Mean plant height $\rceil$ hybrid Pablo§ $(\mathrm{cm})$ & 267 & 289 & 345 & 389 \\
\hline
\end{tabular}

* Significant at the 0.05 probability level.

** Significant at the 0.01 probability level.

*** Significant at the 0.001 probability level.

† NS, not significant $(\alpha=0.05)$; SH, significantly different from hybrid mean yield, at $\alpha=0.01 ; \mathrm{NSH}$, not significantly different from hybrid mean yield; a, Caufa was best hybrid; b, Omba was best hybrid; c, Pablo was best hybrid.

‡ Variance components were multiplied by 100 for better readability.

$\S$ Hybrid with highest yield across all 37 trials.

ๆ Only available for 2009 trials, with two, four, five, and two trials respectively for low-, mid-low-, mid-high-, and high-yielding groups. 


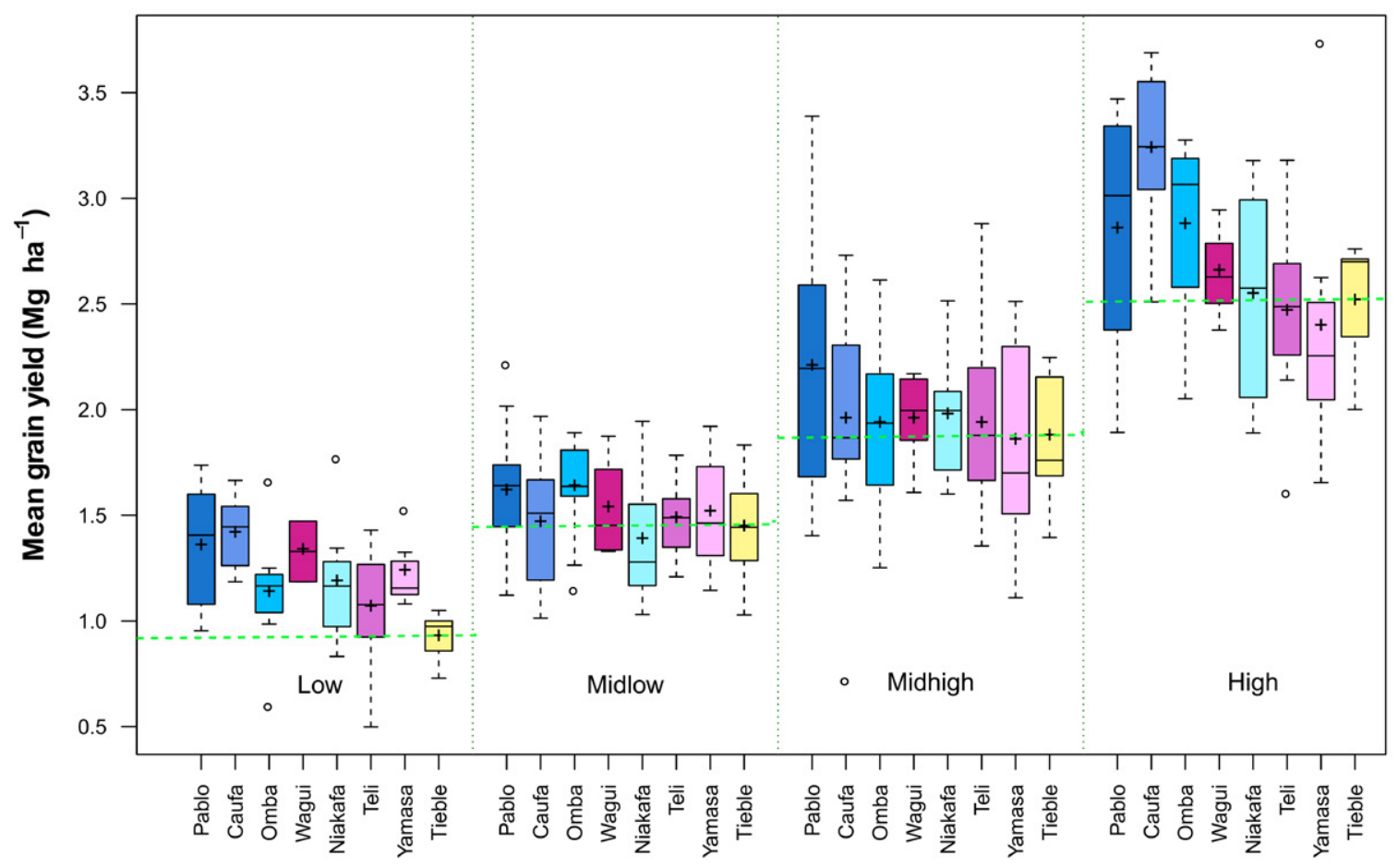

Hybrids and the local check in different productivity groups

Fig. 2. Individual trial grain yields ( $\mathrm{Mg} \mathrm{ha}^{-1}$ ) of hybrids and the local check 'Tieble' within productivity level (see Table 4) presented as boxplots where the midline denotes the genotype median, the colored box corresponds to $25 \%$ above and $25 \%$ below the median, the plus sign denotes the mean, whiskers indicate the total range, and circles show outlier values. Genotypes are sorted within productivity levels based on their overall mean grain yield. The hybrid Wagui was only tested in 2009 and present in two, four, five, and two trials in the low-, mid-low-, mid-high-, and high-yielding groups, respectively.

similar dynamic stability estimates and showed an additive behavior paralleling the environmental trend lines, and Pablo's superiority over Tieble remained constant. Caufa $(b=1.49)$ and Yamassa $(b=0.91)$, in contrast, showed substantially higher and lower dynamic yield stability than Tieble, respectively, with their yield superiorities over Tieble increasing in the higher- (Caufa) and loweryielding (Yamassa) environments.

The minimum hybrid yield superiority required for farmers to recover the seed price was calculated to be $0.05 \mathrm{Mg} \mathrm{ha}^{-1}$ based on the cost of seed $\left(1.55 € \mathrm{~kg}^{-1}\right.$, the current maximum retail price), a conservatively high estimate of seed required to sow one hectare $(5 \mathrm{~kg})$, and the farmgate price for grain at harvest time $\left(0.15 € \mathrm{~kg}^{-1}\right)$. The hybrid yield superiorities over Tieble were, on average, higher than this break-even value for all of the eight hybrids (across all 37 environments) (Table 3). The overall highest-yielding hybrid, Pablo, had mean yield superiorities higher than the break-even point in all four yield-productivity groups (Table 4), as did Omba and Wagui.

All experimental pure line varieties yielded less than Tieble, with 0.02 to $0.42 \mathrm{Mg} \mathrm{ha}^{-1}(1-26 \%)$ yield inferiorities averaged across the 37 trials. The second local check variety, DouaG, also yielded slightly less than Tieble.

The plant height of all experimental hybrids and pureline varieties (except Jamajigi) was $>3 \mathrm{~m}$, similar to Tieble (Table 3). The experimental hybrids exhibited photoperiod sensitivity similar to both local checks, with $\mathrm{Kp}$ values varying between 0.75 and 0.92 (Table 3). In contrast, seven of the eight PLECs showed considerably less photoperiodsensitivity indices (ranging from -0.03 to 0.58 ), with only Jamajigi being similar to Tieble. All photoperiod-sensitive varieties matured in the same period as Tieble, whereas the less photoperiod-sensitive varieties matured earlier, as indicated by their earlier heading dates (Table 3).

\section{DISCUSSION}

\section{Pertinence of Results for Smallholder Sorghum Producers in WCA}

The wide range of sowing dates, rainfall, cultural practices, soil types, and productivity levels sampled in this study allowed a robust assessment of the tall guinea-race sorghum hybrids for performance under smallholder sorghum producers' cultivation environments in Mali. The repeatabilities of the single on-farm trials for grain yield were generally high (Supplemental Table S2), indicating the statistical relevance of this dataset and the quality of the data obtained from onfarm trials. They also showed the feasibility of effectively discriminating among contrasting genotypes under low- and high-productivity conditions in these on-farm yield trials, as was previously reported by Rattunde et al. (2013, 2016).

Although fertilizer was provided to farmers to help obtain better repeatabilities under the frequently heterogeneous field conditions, the productivity levels still covered 
the spectrum from below the current Malian average of 1.0 $\mathrm{Mg} \mathrm{ha}^{-1}$ (FAOSTAT, 2015) to well over double that level. Farmers were free to apply the fertilizer according to their own practice, resulting in many applications after the first weeding, as is typical, and thus often too late for the applied phosphorus (P) to benefit that year's growth (Schenk and Barber, 1979; Nord et al., 2011).

Tieble, the local check used in our study, is widely cultivated by Malian farmers and exhibited stable grain yield across the heterogeneous cropping conditions in this study (Fig. 1). It thus provided a good standard for comparing productivity of the new tall hybrids.

\section{Extent and Nature of Genotype-by- Environment Interaction}

The GEI across all environments was significant but poorly explained by factors such as productivity, year, or zone. Overall, the significant GEI variance was smaller than genotypic variance (Table 2) and appeared to be primarily attributable to interaction at the individual farmer-field level, as was previously observed in trials of shorter hybrids (Rattunde et al., 2013); hence, there is no a priori need to examine hybrid performances within specific mega-environments, but the differences in hybrid superiority relative to the local check across productivity levels suggested that testing across an ample range of onfarm productivity conditions would be worthwhile.

\section{Tall Hybrid On-Farm Yield Performance}

The yield superiorities of the tall hybrids over the welladapted local variety Tieble were sufficiently large to be of importance to sorghum farmers in WCA. The $0.28-\mathrm{Mg} \mathrm{ha}^{-1}$ average yield superiority of the best hybrid Pablo (Table 3) was substantial in comparison to farmers' typical yields of only $1.00 \mathrm{Mg} \mathrm{ha}^{-1}$ in Mali (FAOSTAT, 2015). Furthermore, the relative yield superiorities were even larger in the lowest-productivity conditions (Table 4), under which the majority of sorghum farmers in Mali grow sorghum (Leiser et al., 2012; Rattunde et al., 2016). Higher yield superiorities of hybrids over pure-line check varieties under stressed environments were previously observed in sorghum (Haussmann et al., 1998) and other crops (Bidinger et al., 1994; Tollenaar and Wu, 1999; Betrán et al., 2003; Yadav et al., 2014).

The yield superiorities of the tall hybrids were, in general, smaller than those of shorter-stature hybrids (Rattunde et al., 2013), averaging only 9\% for tall hybrids across all environments (Table 3 ), as compared with 28\% for shorter hybrids (Rattunde et al., 2013). The same was true on the basis of individual hybrids, where the average yield superiority of tall hybrids ranged from 3 to 17\% (0.06$0.28 \mathrm{Mg} \mathrm{ha}^{-1}$ ), whereas for shorter hybrids, it varied from 17 to $37 \%$ (0.27-0.60 $\mathrm{Mg} \mathrm{ha}^{-1}$ ) (Rattunde et al., 2013). Yet the yield superiority of tall hybrids equaled or surpassed that of the short hybrids under the lowest-productivity conditions (averaging 34\% for tall hybrids and 24\% for short hybrids). Thus, a major difference between tall and short hybrids appears to be the greater yield response to improved productivity conditions by short hybrids as compared with tall hybrids. The short hybrids, however, maintained a stable yield superiority, expressed on a percentage basis, over increasing productivity levels (Rattunde et al., 2013), whereas the tall hybrids only exhibited a constant absolute yield superiority (Supplemental Fig. S2).

Comparisons between the tall and short sorghum hybrids is facilitated by their having been evaluated across a similar sample of environments, with trials of tall hybrids and short hybrids conducted in the same villages each year. Also, Tieble was used in both trial series, as the check and its average yield were nearly identical across both the short $\left(1.64 \mathrm{Mg} \mathrm{ha}^{-1}\right)$ and tall hybrid $\left(1.65 \mathrm{Mg} \mathrm{ha}^{-1}\right)$ trial series. The mean yield of Tieble did differ between the set of trials classified as low productivity for the short$\left(1.16 \mathrm{Mg} \mathrm{ha}^{-1}\right.$ ) and tall-hybrid trials (0.91 $\left.\mathrm{Mg} \mathrm{ha}^{-1}\right)$, but it was comparable when the tall hybrid experiments under low and mid-low productivity levels were averaged (1.20 Mg ha ${ }^{-1}$, Supplemental Table 5). Thus, for a more appropriate comparison of short and tall hybrids under low productivity conditions, the tall hybrid yields were averaged across low and mid-low productivity levels (Supplemental Table S4 and S5). Using this new lowproductivity grouping of tall hybrid environments, the best tall hybrid, Pablo, showed 24\% yield superiority over Tieble, whereas the best short hybrid, Fadda, exhibited $32 \%$ superiority over Tieble under low-productivity conditions, despite both hybrids having the same male parent.

The different yield response of tall versus short hybrids is expected to have a physiological basis, as there were no observable differences for frequency of lodging. van Oosterom and Hammer (2008) observed that a short sorghum hybrid exhibited larger increases in grain number in favorable environments, as measured by growth rates at anthesis under increasing nitrogen availability compared with a tall hybrid. This difference was attributed to differential partitioning of dry matter to the reproductive tissue.

Despite the relatively larger yield advantage of short sorghum hybrids, factors such as competitiveness with weeds (Traore et al., 2003) and the preference for and possible benefit of taller plant types for reducing risks of transhumant cattle grazing and bird damage may still lead farmers to grow tall hybrids. Furthermore, because sorghum is mostly produced under low soil-P conditions in WCA, the actual height attained may be considerably less than its genetically potential height, with low $\mathrm{P}$ reducing sorghum height by $1 \mathrm{~m}$ or more (Leiser et al., 2015). For example, the height of tall hybrids in the lowest-productivity group of this study averaged only $285 \mathrm{~cm}$ as compared with $401 \mathrm{~cm}$ in the highest-productivity group (Table 4). Thus, these tall 
hybrids, even under low-productivity conditions, are able to exceed the minimum height $(2.5 \mathrm{~m})$ needed to avoid losses from animal grazing at maturity. Examination of the relative economic values of taller, likely higher-biomass plant types versus shorter sorghum plant types with potentially higher stover digestibility for livestock feed would be worthwhile, particularly based on initial results that show a $1.1 \%(P<0.001)$ increase of in vitro digestibility for each centimeter reduction of stem internode length (F. Rattunde, personal communication, 2016).

\section{Risks and Opportunities of Producing Tall Sorghum Hybrids}

The new tall hybrids should represent a low risk of yield inferiority relative to local, well-adapted varieties for farmers needing to choose between these two options. Furthermore, the frequency of inferiority was even lower $(2.3 \%)$ (Table 4) in the lowest-productivity trials that corresponded to the most common sorghum production conditions in WCA. The highest-yielding hybrid had only a single case of significant yield inferiority in 37 trials, and this occurred under higher, less typical production conditions.

The minimum hybrid yield superiority required for farmers to recover the seed price was actually very low, being only $0.05 \mathrm{Mg} \mathrm{ha}^{-1}$. Thus, farmers' risk of not recouping the value of their investment in purchased seed of a new tall sorghum hybrid is small. Furthermore, the results of this study are conservative, as the experimental hybrids tested here resulted from very weak selection intensity and a small number of parental lines with no prior combining ability testing. A dedicated full-scale hybrid breeding program with larger numbers of parental lines, higher selection intensities, and broader genetic diversity can be anticipated to produce even larger hybrid yield superiorities and lower risks of hybrid yield inferiority for smallholder farmers.

Already, both male and female farmers in Mali have access to seed of the guinea-race hybrids tested in this study (Weltzien et al., 2010), and adoption is increasing (Smale et al., 2014) despite farmers' unfamiliarity with hybrid seed and the cultural norm of not purchasing sorghum seed. The annual doubling of hybrid sorghum seed production by farmer seed-producer organizations during the past $6 \mathrm{yr}$ in Mali attests to the interest in and adoption of guinea-race hybrid sorghum (E. Weltzien, personal communication, 2016).

A driver for the interest and adoption of the new guinearace sorghum hybrids is the yield superiorities that have not been matched by formally bred pure-line varieties. The $0.43-\mathrm{Mg} \mathrm{ha}{ }^{-1}$ yield superiority of Pablo under the lowest productivity level of approximately $1 \mathrm{Mg} \mathrm{ha}^{-1}$ (Table 4) can make the difference between food insecurity and food security plus income for smallholder farmers. Hybrids, which in addition to higher yields have farmer-preferred characteristics such as taller height, lax panicles, and good grain quality and storability, represent a truly new option for WCA farmers that should be pursued by properly scaled hybrid breeding programs. The balance between sufficient plant height and the greater yield potential of shorter hybrids could be examined with medium tall hybrids, particularly when breeding for farmers operating under low-input conditions.

\section{CONCLUSIONS}

From the advances in Malian sorghum hybrid development and adoption of these farmer-preferred hybrids, it can be concluded that guinea-race sorghum hybrid breeding is a very promising strategy to help improve the livelihood of many smallholder farmers. Hybrids that have, in addition to higher yields, farmer-preferred characteristics, such as taller height, lax panicles, and high seed or grain quality, should be pursued in breeding programs. These hybrids bear a great potential to boost grain yield production under smallholder farmers' low-productivity conditions, because these hybrids will be adopted by farmers and thus will not be a mere scientific advancement. For future efforts, medium tall hybrids that have all the other farmer-preferred traits and are specifically bred for lowinput conditions can be considered. Such hybrids would have most probably a higher harvest index and would still show a high adoption rate among farmers.

\section{Conflict of Interest}

The authors declare there to be no conflict of interest.

\section{Supplemental Material Available}

Supplemental material for this article is available online.

\section{Acknowledgments}

The authors thank Malian farmers for conducting the trials and field staff of the Association des Organisations de Paysans Professionnels (AOPP), Union Local de Producteurs de Céréales (ULPC), and Association d'Eveil au Développement Durable (AMEDD). The Rockefeller Foundation support for hybrid parental materials creation, and the McKnight Foundation, the Bill and Melinda Gates Foundation, and the Bundesministerium für Wirtschaftliche Zusammenarbeit (BMZ) funding for farmer field testing are greatly acknowledged. M. Kante acknowledges a grant by the BMZHeterosis Project (ICRISAT Project 13.1432.7-001.00). The work was undertaken as a part of the CGIAR Research Program on Dryland Cereals.

\section{References}

Bationo, A., J. Kihara, B. Vanlauwe, B. Waswa, and J. Kimetu. 2007. Soil organic carbon dynamics, functions and management in West African agro-ecosystems. Agric. Syst. 94:13-25. doi:10.1016/j.agsy.2005.08.011

Becker, H.C., and J. Leon. 1988. Stability analysis in plant breeding. Plant Breed. 101:1-23. doi:10.1111/j.1439-0523.1988. tb00261.x 
Betrán, F.J., D. Beck, M. Bänziger, and G.O. Edmeades. 2003. Genetic analysis of inbred and hybrid grain yield under stress and nonstress environments in tropical maize. Crop Sci. 43:807-817. doi:10.2135/cropsci2003.8070

Bidinger, F.R., E. Weltzien, R.V. Mahalakshmi, S.D. Singh, and K.P. Rao. 1994. Evaluation of landrace topcross hybrids of pearl millet for arid zone environments. Euphytica 76:215226. doi:10.1007/BF00022166

Billot, C., P. Ramu, S. Bouchet, J. Chantereau, M. Deu, L. Gardes et al. 2013. Massive sorghum collection genotyped with SSR markers to enhance use of global genetic resources. PLoS One 8(4):e59714. doi:10.1371/journal.pone.0059714

Blum, A., G. Golan, J. Mayer, B. Sinmena, and T. Obilana. 1992. Comparative productivity and drought response of semitropical hybrids and open-pollinated varieties of sorghum. J. Agric. Sci. 118:29-36. doi:10.1017/S0021859600067976

Chantereau, J., J.-F. Cruz, A. Ratnadass, and G. Trouche. 2013. Le sorgho. Quae, INRA- RD 10-78026. (In French.) INRA, Versailles, France.

Clerget, B., and H. Rattunde. 2007. An easy way to assess photoperiod sensitivity in sorghum: Relationships of the vegetativephase duration and photoperiod sensitivity. International Crops Research Institute for the Semi-Arid Tropics, Patancheru, India.

Conner, A. 1927. Hybrid vigor in sorghum. Texas Agricultural Experiment Station, College Station, TX.

Dahlberg, J.A. 2000. Classification and characterization of sorghum. In: C. Wayne Smith and R. Frederiksen, editors, Sorghum: Origin, history, technology and production. John Wiley, Hoboken, NJ. p. 99-130.

de Mendiburu, F. 2009. Agricolae: Una herramienta de análisis estadístico para la investigación agrícola. (In Spanish.) Univ. Nacional de Ingeniería, Lima, Peru.

FAOSTAT. 2015. FAOSTAT. FAO, Rome. http://faostat3.fao. org/download/ (accessed 10 Mar. 2016).

Finlay, K.W., and G.N. Wilkinson. 1963. The analysis of adaptation in a plant breeding programme. Aust. J. Agric. Res. 14:742-754. doi:10.1071/AR9630742

Folkertsma, R.T., H.F.W. Rattunde, S. Chandra, G.S. Raju, and C.T. Hash. 2005. The pattern of genetic diversity of Guinearace Sorghum bicolor (L.) Moench landraces as revealed with SSR markers. Theor. Appl. Genet. 111:399-409. doi:10.1007/ s00122-005-1949-0

Gauch, H.G. 2013. A simple protocol for AMMI analysis of yield trials. Crop Sci. 53:1860-1869. doi:10.2135/cropsci2013.04.0241

Gauch, H.G., and R.W. Zobel. 1990. Imputing missing yield trial data. Theor. Appl. Genet. 79:753-761. doi:10.1007/BF00224240

Gauch, H.G., and R. Zobel. 1988. Predictive and postdictive success of statistical analyses of yield trials. Theor. Appl. Genet. 76:1-10. doi:10.1007/BF00288824

Harlan, J.R., and J.M.J. de Wet. 1972. A simplified classification of cultivated sorghum. Crop Sci. 12:172-176. doi:10.2135/crops ci1972.0011183X001200020005x

Haussmann, B.I.G., A.B. Obilana, P.O. Ayiecho, A. Blum, W. Schipprack, and H.H. Geiger. 1999. Quantitative-genetic parameters of sorghum [Sorghum bicolor (L.) Moench] grown in semi-arid areas of Kenya. Euphytica 105:109-118. doi:10.1023/A:1003469528461

Haussmann, B.I.G., A.B. Obilana, P.O. Ayiecho, A. Blum, W. Schipprack, and H.H. Geiger. 2000. Yield and yield stability of four population types of grain sorghum in a semiarid area of Kenya. Crop Sci. 40:319-329. doi:10.2135/ cropsci2000.402319x
Haussmann, B.I.G., A.B. Obilana, A. Blum, P.O. Ayiecho, W. Schipprack, and H.H. Geiger. 1998. Hybrid performance of sorghum and its relationship to morphological and physiological traits under variable drought stress in Kenya. Plant Breed. 117:223-229. doi:10.1111/j.1439-0523.1998.tb01930.x

Haussmann, B.I.G., A.T. Obilana, and H.H. Geiger. 1997. Heterosis of grain sorghum under extremely variable growing conditions in semi-arid areas of Kenya. In: The genetics and exploitation of heterosis in crops: An international symposium, Mexico, D.F. 17-22 Aug. 1997. CIMMYT, Mexico, D.F. p. 320-321.

Jones, M.J., and A. Wild. 1975. Soils of the West African savanna; the maintenance and improvement of their fertility. Commonwealth Agricultural Bureaux, Wallingford, UK.

Kimber, C., J. Dahlberg, and S. Kresovich. 2013. The gene pool of Sorghum bicolor and its improvement. In: A.H. Paterson, editor, Genomics of the Saccharinae. Vol. 11. p. 23-41. doi:10.1007/978-1-4419-5947-8_2

Leiser, W.L.W., H.F.W. Rattunde, H.-P. Piepho, E. Weltzien, A. Diallo, A.E. Melchinger et al. 2012. Selection strategy for sorghum targeting phosphorus-limited environments in West Africa: Analysis of multi-environment experiments. Crop Sci. 52:2517-2527. doi:10.2135/cropsci2012.02.0139

Leiser, W.L., H.F.W. Rattunde, H.-P. Piepho, E. Weltzien, A. Diallo, A. Toure, and B.I.G. Haussmann. 2015. Phosphorous efficiency and tolerance traits for selection of sorghum for performance in phosphorous-limited environments. Crop Sci. 55:1152-1162. doi:10.2135/cropsci2014.05.0392

Lin, C.S., M.R. Binns, and L.P. Lefkovitch. 1986. Stability analysis: Where do we stand? Crop Sci. 26:894-900. doi:10.2135/ cropsci1986.0011183X002600050012x

Nord, E.A., K. Shea, and J.P. Lynch. 2011. Optimizing reproductive phenology in a two-resource world: A dynamic allocation model of plant growth predicts later reproduction in phosphorus-limited plants. Ann. Bot. (Lond.) 108:391-404. doi:10.1093/aob/mcr143

Paderewski, J. 2013. An R function for imputation of missing cells in two-way data sets by EM-AMMI algorithm. Commun. Biometry Crop Sci. 8:60-69.

Piepho, H.-P., and J. Möhring. 2007. Computing heritability and selection response from unbalanced plant breeding trials. Genetics 177:1881-1888. doi:10.1534/genetics.107.074229

Rattunde, H., E. Weltzien, and P. Bramel-Cox. 1997. Population improvement of pearl millet and sorghum: Current research, impact and issues for implementation. In: Proceedings of the International Conference on Genetic Improvement of Sorghum and Pearl Millet, Lubbock, TX. 23-27 Sept. 1996. INTSORMIL, Lincoln, NE. p. 188-212.

Rattunde, H.F.W., S. Michel, W.L. Leiser, H.-P. Piepho, C. Diallo, K. vom Brocke et al. 2016. Farmer participatory early-generation yield testing of sorghum in West Africa: Possibilities to optimize genetic gains for yield in farmers' fields. Crop Sci. 56:2493-2505. doi:10.2135/cropsci2015.12.0758

Rattunde, H.F.W., E. Weltzien, B. Diallo, A.G. Diallo, M. Sidibe, A.O. Touré et al. 2013. Yield of photoperiod-sensitive sorghum hybrids based on guinea-race germplasm under farmers' field conditions in Mali. Crop Sci. 53:2454-2461. doi:10.2135/cropsci2013.03.0182

R Development Core Team. R. 2011. R: A language and environment for statistical computing. R Foundation for Statistical Computing, Vienna, Austria. 
Schenk, M.K., and S.A. Barber. 1979. Phosphate uptake by corn as affected by soil characteristics and root morphology. Soil Sci. Soc. Am. J. 43:880-883. doi:10.2136/ sssaj1979.03615995004300050012x

Smale, M., A. Assima, E. Weltzien, and F. Rattunde. 2014. An overview and economic assessment of sorghum improvement in Mali. International development working paper 137. Michigan State Univ., East Lansing, MI.

Stephens, J.C., and R.F. Holland. 1954. Cytoplasmic male-sterility for hybrid sorghum seed production. Agron. J. 46:20-23. doi:10.2134/agronj1954.00021962004600010006x

Tollenaar, M., and J. Wu. 1999. Yield improvement in temperate maize is attributable to greater stress tolerance. Crop Sci. 39:1597-1604. doi:10.2135/cropsci1999.3961597x

Touré, A.B., and J.F. Scheuring. 1982. Presence de genes mainteneurs de l'androsterilité cytoplasmique parmi les variétés locales de sorgho au Mali. (In French.) L'agronomie Trop. 37:362-365.

Traore, S., C.M. Stephen, A.R. Martin, D.A. Mortensen, and J.J. Spotanski. 2003. Velvetleaf interference effects on yield and growth of grain sorghum. Agron. J. 95:1602-1607 doi:10.2134/agronj2003.1602.

van Oosterom, E.J., and G.L. Hammer. 2008. Determination of grain number in sorghum. Field Crops Res. 108:259-268. doi:10.1016/j.fcr.2008.06.001
VSN International. 2014. GenStat for Windows 17th ed. VSN International, Hemel Hempstead, UK.

VSN International. 2015. Genstat for Windows 18th ed. VSN International, Hemel Hempstead, UK.

Weltzien, E. 2014. Sorghum in Africa: Research opportunities and priorities. Technical Center for Agricultural and Rural Cooperation, Wageningen, the Netherlands.

Weltzien, E., M. Kanouté, A. Toure, F. Rattunde, B. Diallo, I. Sissoko et al. 2008. Sélection participative des variétés de sorgho à l'aide d'essais multilocaux dans deux zones cibles. (In French.) Cah. Agric. 17:134-139.

Weltzien, E., M. Sidibe, B. Diallo, Y. Traore, M. Coulibaly, K. vom Brocke et al. 2010. Seed systems II: Sustaining farmermanaged seed initiatives for sorghum and pearl millet in Mali, Niger, and Burkina Faso. McKnight Seed System II: Annual report. ICRISAT, Patancheru, India.

de Wet, J.M.J., J.R. Harlan, and B. Kurmarohita. 1972. Origin and evolution of Guinea sorghums. East Afr. Agric. For. J. 38:114-119.

de Wet, J.M.J., and J.P. Huckabay. 1967. The origin of Sorghum bicolor. II. Distribution and domestication. Evolution (N. Y.) 21:787-802.

Yadav, A.K., R.K. Arya, and M.S. Narwal. 2014. Screening of pearl millet $F_{1}$ hybrids for heat tolerance at early seedling stage. Adv. Agric. 2014:231301. doi:10.1155/2014/231301 